\title{
Leishmania braziliensis: Partial Control of Experimental Infection by Interleukin-12 p40 Deficient Mice
}

\section{Sebastião Martins de Souza-Neto, Cláudia Martins Carneiro*, Leda Q uercia Vieira**/++, Luís Carlos Crocco Afonso/ ${ }^{+}$}

\begin{abstract}
Departamento de Ciências Biológicas, Instituto de Ciências Exatas e Biológicas, Nupeb *Departamento de Análises Clínicas, Escola de Farmácia, Universidade Federal de Ouro Preto, 35400-000 Ouro Preto, MG, Brasil **Departamento de Bioquímica e Imunologia, Universidade Federal de Minas Gerais, Belo Horizonte, MG, Brasil
\end{abstract}

Resistance to infection by Leishmania major has been associated with the development of a Th1 type response that is dependent on the presence of interleukin 12 (IL-12). In this work the involvement of this cytokine in the response to infection by L. braziliensis, a less virulent species in the mouse model, was evaluated. Our results show that while interferon (IFN- $\gamma$ ) deficient (-/-) mice inoculated L. braziliensis develop severe uncontrolled lesions, chronic lesions that remained under control up to 12 weeks of infection were observed in $I L-12 p 40$-/- mice. IL $12 p 40$-/- mice had fewer parasites in their lesions than IFN- $\gamma-/$ - mice. Lymph node cells from IL-12p40 -/- were capable of producing low but consistent levels of IFN- $\gamma$ suggestive of its involvement in parasite control. Furthermore, as opposed to previous reports on L. major-infected animals, no switch to a Th2 response was observed in IL$12 p 40$-/- infected with L. braziliensis.

Key words: cutaneous leishmaniasis - Leishmania braziliensis - interleukin 12

The great majority of studies related to the immune response in cutaneous leishmaniasis using the murine model have been carried out using Leishmania major as the prototype species. These studies have established that resistance to infection by this parasite is associated with the development of Leishmania-specific Th1 cells while susceptibility and disease progression is related to a Th2 type response (Heinzel et al. 1989, 1991, Liew 1989, Scott 1989, 1991, Scott et al. 1989). While this paradigm seems to apply to most circumstances in the case of $L$. major, several studies have demonstrated that, especially in mice infected by other Leishmania species that also cause cutaneous leishmaniasis such as L. amazonensis, the association of susceptibility to infection and the presence of a Th2 response is not always observed (Afonso $\&$ Scott 1993, Soong et al. 1997, Jones et al. 2002).

With regard to the role of cytokines in the development of the resistant phenotype, it has been demonstrated that interferon- $\gamma($ IFN- $\gamma$ ) and interleukin (IL)-12 are necessary not only in the initial steps of the infection, but also to maintain an established response against this parasite (Belosevic et al. 1989, Wang et al. 1994, Mattner et al. 1996, 1997b).

The importance of IL-12 in the response to Leishmania is attributed to its involvement in the development of Th1 cells (Hsieh et al. 1993, Trinchieri 1993, Magram et al.

\footnotetext{
Financial support: Capes

${ }^{+}$Corresponding author. Fax: +55-31-3559.1680. E-mail: afonso@ nupeb.ufop.br

${ }^{++} \mathrm{CNPq}$ felowship
}

Received 10 November 2003

Accepted 15 March 2004
1996), however more recent studies have demonstrated that under certain circumstances Th1 development can be achieved in the absence of IL-12 (Scharton-Kersten et al. 1996, Brombacher et al. 1999).

Several studies with murine models of $L$. braziliensis have demonstrated that all mouse strains tested are resistant to infection by this parasite (Childs et al. 1984, Samuelson et al. 1991, Barral-Netto et al. 1992, 1993, Lima et al. 1999) and that this resistance is dependent on IFN$\gamma$ activity (DeKrey et al. 1998). Since L. braziliensis infection does not induce significant levels of IL-4, we decided to use this parasite species to further clarify the role of IL12 in the control of infection by intracellular protozoan parasites. Our results show that, contrary to what has been observed with L. major, L. braziliensis-infected IL12 p40 -/- mice partially control parasite growth. This observation was associated with the production of low levels of IFN- $\gamma$ and TNF but also of IL-4, suggesting that, when infected with L. braziliensis, IL-12p40-/- mice do not default to a Th2 type response.

\section{MATERIALS AND METHODS}

Animals - C57BL/6 mice were obtained from Cebio (Instituto de Ciências Biológicas, UFMG, Belo Horizonte, MG, Brazil). IFN- $\gamma-/-$ mice were obtained from Jackson Farms (Glensville, NJ, US). IL-12p40-/- were kindly provided by Dr Luiz Vicente Rizzo from the Departamento de Imunologia, Universidade de São Paulo. Both genetically deficient strains were bred in micro isolators, given sterile food and water ad libidum. Experimental animals were males and females, 4-8 week old and were kept in a conventional animal facility. The animals were reared and used according to the Guide for the Care and Use of Laboratory Animals of the National Research Council (1996).

Parasites and infection protocol - L. (Viannia) braziliensis promastigotes, strain M2903 (MHOM/BR/75/ M2903 - a gift from Dr Maria Norma Melo, Universidade 
Federal de Minas Gerais, were cultured in Grace's insect medium (Gibco, Grand Island, NY, US) supplemented with $20 \%$ heat-inactivated FCS (Nutricell, Campinas, SP, BR), 2 $\mathrm{mM}$ L-glutamine (Gibco) and $10 \mu \mathrm{g} / \mathrm{ml}$ gentamycin sulfate (Schering Plough, Rio de Janeiro, BR), at $26^{\circ} \mathrm{C}$. Promastigotes were collected at the stationary phase (5th day of culture), centrifuged at $1540 \mathrm{x} g$ at $4^{\circ} \mathrm{C}$ for $20 \mathrm{~min}$ and washed in phosphate buffered saline (PBS). Mice were inoculated with $1 \times 10^{7}$ or $1 \times 10^{5}$ stationary phase promastigotes (5th day of culture) in the left hind footpad. Lesion development was measured during the course of infection with a dial micrometer model 1015MA (LS Starret Co., Itu, SP, Brazil) and expressed as the difference in size between the infected footpad and the contralateral uninfected footpad.

Antigen preparation - Leishmania antigen was obtained from logarithmic phase cultures of $L$. braziliensis promastigotes. Promastigotes were washed twice in PBS and pellets were stored frozen at $-20^{\circ} \mathrm{C}$ until enough material was accumulated for preparation of antigen. Pellets were submitted to seven cycles of freezing in liquid nitrogen followed by thawing at $37^{\circ} \mathrm{C}$. The preparations were visually inspected for the presence of intact parasites. Protein content of preparations was assayed by the Lowry method (Lowry et al. 1951) and adjusted to $1 \mathrm{mg}$ protein/ $\mathrm{ml}$. Antigen preparation was aliquoted and stored frozen at $-70^{\circ} \mathrm{C}$. Antigens were thawed immediately before use in cell cultures.

Estimation of parasite load - The number of parasites in the footpad was estimated by limiting dilution assay. Mice were sacrificed and the whole lesion was removed and weighed. A fragment of known weight was obtained and ground in cold PBS containing $10 \mu \mathrm{g} / \mathrm{ml}$ gentamycin (Schering Plough), in glass tissue grinders. Tissue debris were removed by centrifugation at $50 \mathrm{xg}$ for $1 \mathrm{~min}$, the supernatants were transferred to another tube and centrifuged at $1540 \mathrm{xg}$ for $15 \mathrm{~min}$. The pellet was resuspended in $0.5 \mathrm{ml}$ of Grace's medium containing $20 \%$ FCS, 2 mM Lglutamine and $10 \mu \mathrm{g} / \mathrm{ml}$ gentamycin. The parasite suspension was then serially diluted in 10 -fold dilutions in duplicates in $200 \mu \mathrm{l}$ final volume in 96 -well plates. Pipet tips were replaced for each dilution. Plates were incubated for 10 days at $26^{\circ} \mathrm{C}$ and examined under an inverted microscope. Results are expressed as the negative logarithm of the last dilution in which parasites were detected, adjusted for the weight of the tissue sample.

Analysis of cytokine production - Single-cell suspensions were prepared from the popliteal lymph nodes of the infected footpad harvested at 3 or 12 weeks of infection. Cells were adjusted to a concentration of $5 \times 10^{6} / \mathrm{ml}$ in Dulbecco's minimal essential medium (Gibco) containing $10 \%$ fetal calf serum (Nutricell), $2 \mathrm{mM}_{\mathrm{L} \text {-glutamine and }}$ $10 \mu \mathrm{g} / \mathrm{ml}$ gentamycin (Schering Plough) $25 \mathrm{mM} \mathrm{N}-2-$ hydroxiethylpiperazine- $N$ '-2-ethanosulfonic acid (HEPES) and $50 \mu \mathrm{M} 2$-mercaptoethanol, and plated at $0.5 \mathrm{ml}$ per well in 48-well tissue culture plates. Parasite antigen was added at the start of the culture $(50 \mu \mathrm{g} / \mathrm{ml})$. Supernatants were harvested after $24 \mathrm{~h}$ for tumor necrosis factor (TNF) measurement or $72 \mathrm{~h}$ for IFN- $\gamma$ and IL 4 determination.

IFN- $\gamma$ was assayed in a two-site ELISA using a rat anti-IFN- $\gamma$ monoclonal antibody R46A2 (ATCC) and a polyclonal rabbit serum specific for the cytokine, kind gift from Dr Jay Farrell, University of Pennsylvania, PA, US. IFN- $\gamma$ levels were calculated by reference to a standard curve constructed with recombinant cytokine (R\&D Systems, Minneapolis, MN, US). Sensitivity of this method was $0.03 \mathrm{ng} / \mathrm{ml}$. IL-4 was assayed also in a two-site ELISA, using rat anti-IL-4 mAb 11b11 (ATCC) and biotynilated mAb BVD6 (kind gift of Dr Phillip Scott, University of Pennsylvania). IL-4 levels were calculated by reference to a standard curve constructed with recombinant cytokine (R\&D Systems). Sensitivity of this method was $0.06 \mathrm{ng} /$ $\mathrm{ml}$. All monoclonal antibodies were produced in our laboratory, from ascitis from $n u / n u$ mice of various backgrounds.

TNF production was estimated in a bioassay using WEHI cells as described previously (Lattime et al. 1988).

Statistical analysis - All experiments used groups of 4 animals and were repeated twice with similar results. Results are represented as mean + SEM. Differences between groups were compared using the Student's t test.

\section{RESULTS}

Course of L. braziliensis infection in IL-12p40 -/mice - Previous studies have demonstrated that IFN- $\gamma$ is essential to the control of L. braziliensis infection in BALB/c mice. Since IL-12 is involved in the induction of IFN- $\gamma$ production by NK as well as T cells, we decided to evaluate the role of IL-12 in the control of this parasite. While lesions in C57BL/6 mice inoculated with $1 \times 10^{7}$ stationary phase promastigotes begin to decrease in size 3 weeks after infection and are completely healed after 6 to 7 weeks, IFN- $\gamma-/$ - mice developed severe uncontrolled lesions and had to be sacrificed after 4 weeks of infection (Fig. 1). On the other hand, lesion growth in IL-12p40 -/mice infected with $L$. braziliensis reached a maximum after 4 weeks of infection without further increase in size for at least another 8 weeks, suggesting a partial control of the parasite even in the absence of IL-12.

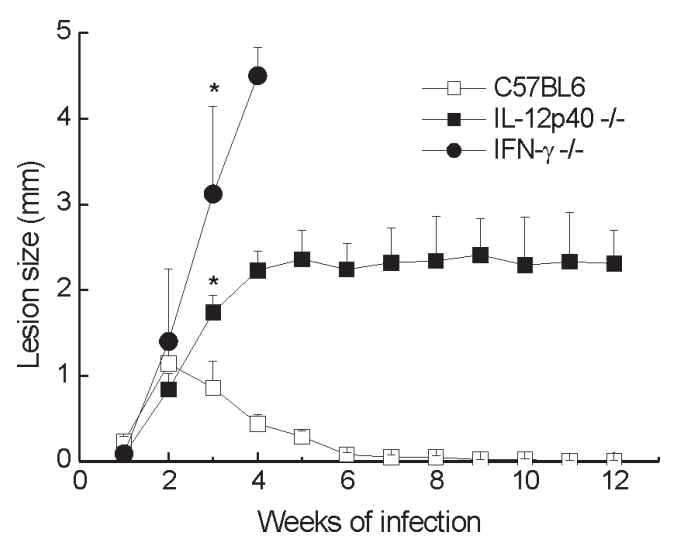

Fig. 1: course of Leishmania braziliensis infection. Mice were inoculated in the left hind footpad with $1 \times 10^{7}$ stationary phase $L$. braziliensis promastigotes. Lesion measurements were carried out weekly with a metric caliper. Data represent the mean + SEM of the difference between the infected and contralateral footpad from two experiments with 4 mice per group. IFN- $\gamma-/$ - mice were sacrificed with 4 weeks of infection due to extensive ulceration of the lesions. * $\mathrm{p}<0.05$ for differences in lesion size as compared to the wild type control group from this time point on. 
Lesion development correlated with parasite load at the site of infection. As shown in Fig. 2, while in C57BL/ 6 mice a decrease in lesion parasitism from 3 to 12 weeks of infection was observed $(3.7 \pm 0.7$ at 3 weeks and not detected at 12 weeks), the parasite load in lesions from IL$12 \mathrm{p} 40$-/- slightly increased during the same time period $(4.7 \pm 0.4$ at 3 weeks versus $5.7 \pm 0.5$ at 12 weeks $-\mathrm{p}<$ $0.05)$. On the other hand, IFN- $\gamma-/$ - mice presented much higher numbers of parasites in their lesions $(8.4 \pm 0.9$ at 4 weeks). Although parasite growth in IL-12p40 -/- mice appeared to be controlled at the site of inoculation, dissemination to other organs was not blocked in these animals. Histological examination of liver and spleen demonstrated the presence of the parasite in these organs. Furthermore, small metastatic skin lesions were observed in some animals later in the course of infection (data not shown). No dissemination of the parasite to viscera or presence of metastatic lesions was observed in infected C57BL/6 control mice.

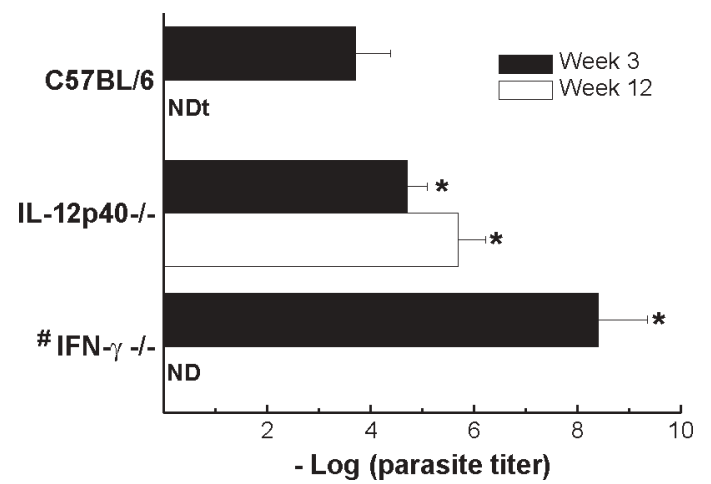

Fig. 2: parasite load in lesions from mice infected with Leishmania braziliensis. Mice were inoculated in the left hind footpad with $1 \mathrm{x}$ $10^{7}$ stationary phase promastigotes. At the indicated time animals were sacrificed and the parasite load determined by limiting dilution assay. Bars represent the mean + SEM of the $-\log$ of the parasite titer from lesions of 4 mice per group at each time point. $* p<0.01$ as compared to wild type control. \#Results from IFN- $\gamma-/-$ mice were obtained at 4 weeks after infection. ND: not done. NDt: not detected.

Similar results were obtained with animals inoculated with $1 \times 10^{5}$ promastigotes with regard to both lesion development and tissue parasitism. C57BL/6 mice developed small lesions that completely healed after seven weeks of infection. On the other hand, IL-12p40 -/- mice developed chronic lesions identical in size to those of mice infected with $1 \times 10^{7}$ parasites (data not shown). The parasite load of animals infected with $1 \times 10^{5}$ promastigotes was $1 \times 10^{2}$ and $1 \times 10^{7.5}$ for C57BL/6 and IL-12p40 -/animals, respectively, at 12 weeks of infection.

Cytokine production - In order to investigate the immune response to the parasite, lymph node cells were stimulated in vitro with $L$. braziliensis antigen and cytokine production measured after 24 or $72 \mathrm{~h}$. As expected, stimulation of lymph node cells from C57BL/6 mice infected for 3 weeks induced the production of high levels of IFN- $\gamma$ $(75 \pm 39 \mathrm{ng} / \mathrm{ml})$ while only very low levels of this cytokine were detected in the supernatants of IL-12p40 /- stimulated lymph node cells $(0.8 \pm 0.4 \mathrm{ng} / \mathrm{ml})$ (Fig. 3a). At 12 weeks of infection a decrease in the production of IFN- $\gamma$ was detected in the lymph node of C57BL/6 mice (14.8 ng/ $\mathrm{ml})$, probably due to the decrease in the local response caused by the control of the parasite. The level of IFN- $\gamma$ production by cells IL-12p40 -/- mice at this point was similar to that detected at 3 weeks of infection $(0.6 \pm 0.3$ $\mathrm{ng} / \mathrm{ml})$.

With regard to IL-4 production, even though slightly higher levels were detected in supernatants from IL-12p40 -/- mice in comparison to C57BL/6 controls, especially at 3 weeks of infection, these differences were not statistically significant (Fig. 3b). Furthermore, IL-12p40 -/- mice produced less IL-4 at 12 weeks of infection than at 3 weeks ( $\mathrm{p}<0.05$ ) indicating that, as opposed to what has been shown in L. major infected mice (Mattner et al.1996, 1997a), the lack of IL-12 during infection with L. braziliensis does not induce a strong polarization towards a Th2 type response. In addition, the levels of IL-4 detected in IL12 p40 -/- mice are much lower than those found in BALB/ c mice infected with L. major (1-2 ng/ml, data not shown).

An interesting observation was made when $24 \mathrm{~h} \mathrm{su}-$ pernatants from infected mice were assayed for the presence of tumor necrosis factor (TNF). At 3 weeks after infection, levels of TNF detected in stimulated supernatants from both C57BL/6 and IL-12p40 -/- were 0.16 \pm 0.04 and $0.34 \pm 0.10 \mathrm{ng} / \mathrm{ml}$, respectively. After 12 weeks of infection, however, a large increase in the levels of TNF was detected in supernatants from L. braziliensis-infected C57BL/6 mice $(3.5 \pm 1.5 \mathrm{ng} / \mathrm{ml})$. This level of TNF production is greater than what is usually observed in L. majorinfected C57BL/6 mice (Vieira et al. 1996). In IL-12p40 -/infected with $L$. braziliensis however, this increase was not detected $(0.8 \pm 0.6 \mathrm{ng} / \mathrm{ml})$ (Fig. 3c).

When animals were infected with 1 × $10^{5}$ promastigotes, a similar cytokine profile was observed in IL-12p40 -/mice, i.e. very low levels of IFN- $\gamma$, IL-4 and TNF, 12 weeks after infection. On the other hand, a decreased production of IFN- $\gamma$ and TNF by lymph node cells from C57BL/6 mice inoculated with $1 \times 10^{5}$ parasites was observed at 12 weeks of infection (1.2 and $0.02 \mathrm{ng} / \mathrm{ml}$, respectively). No change in the production of IL-4 was observed. It is not clear however, whether this decreased production of inflammatory cytokines is responsible for the comparatively higher (but still very low) numbers of parasites found in C57BL/6 mice inoculated with $1 \times 10^{5}$ promastigotes.

\section{DISCUSSION}

The role of IL-12 in the induction of protection against infection by Leishmania has been extensively studied over the past 10 years. Several studies demonstrated that IL-12 production or its administration during the first weeks of infection by L. major is fundamental to the development of a protective response against this parasite (Heinzel et al. 1993, Sypek et al. 1993, Vieira et al. 1994, Scharton-Kersten \& Scott 1995, Mattner et al. 1996), due to the importance of this cytokine in the induction of IFN$\gamma$ production by NK cells and the generation of a Th1 response (Chan et al. 1991, 1992, Hsieh et al. 1993, Macatonia et al. 1993, Seder et al. 1993, Tripp et al. 1993). 
In addition, studies with IL-12 deficient mice infected with L. major demonstrated that this cytokine is important not only for the establishment, but also for the maintenance of the protective response against the parasite (Stobie et al. 2000, Park et al. 2000). However, recent studies have demonstrated that resistance to other intracellular patho-
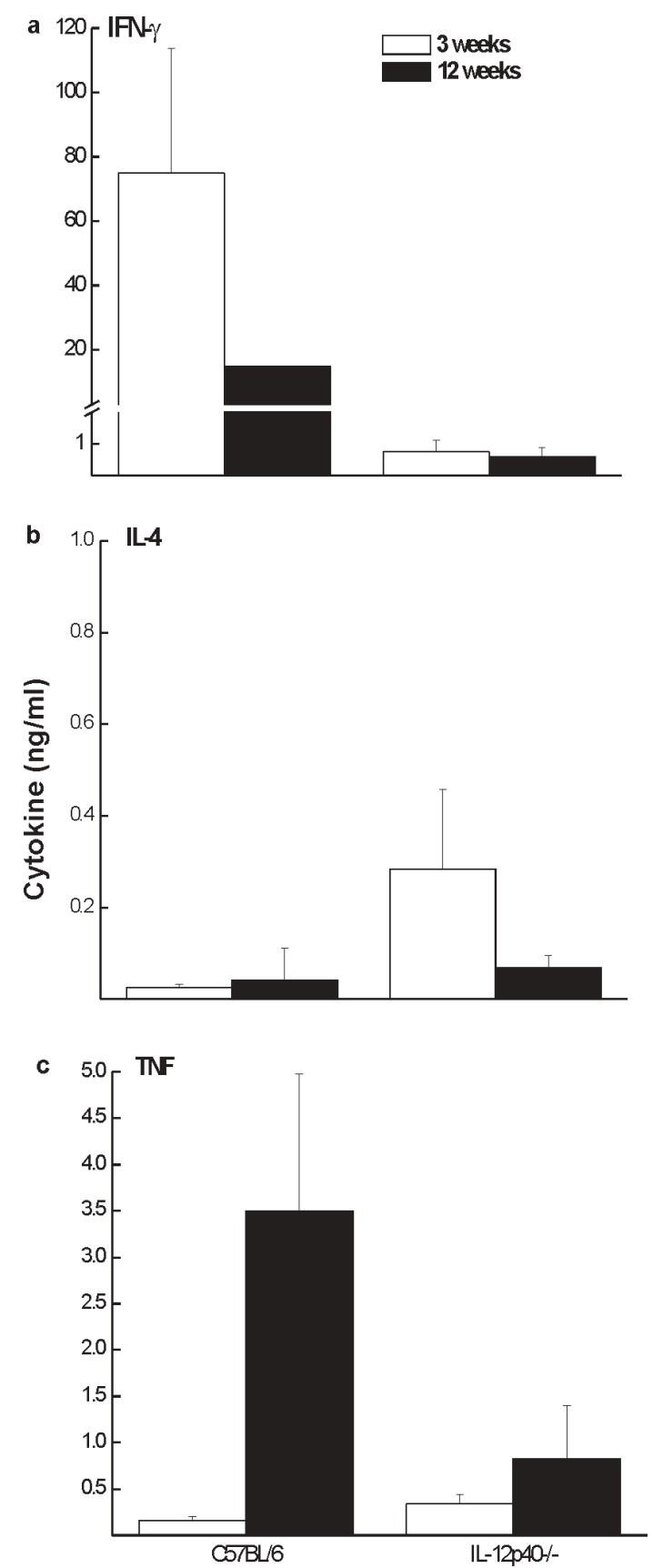

Fig. 3: cytokine production by lymph node cells from mice infected with Leishmania braziliensis. Mice were infected with $1 \mathrm{x}$ $10^{7}$ stationary phase promastigotes and sacrificed at the indicated time points. Cytokine production was assayed in culture supernatants of control (not shown) and antigen-stimulated $(50 \mu \mathrm{g} / \mathrm{ml})$ lymph node cells after 24 (TNF) or $72 \mathrm{~h}$ (IFN- $\gamma$ and IL-4). Cytokine concentration was determined by ELISA (IFN- $\gamma$ and IL-4) or bioassay $(\mathrm{TNF}) . * \mathrm{p}<0.05$ as compared to wild type control. gens can be achieved in the absence of IL-12 (SchartonKersten et al. 1996, Brombacher et al. 1999, Del Rio et al. 2001) and that this resistance may be mediated by IFN- $\gamma-$ producing $\mathrm{CD}^{+} \mathrm{T}$ cells, suggesting that IL-12 may be more important in the effector phase of the response rather than in its priming (Jankovic et al. 2002).

Infection of several inbred mouse strain by $L$. braziliensis, the main causative agent of cutaneous leishmaniasis in Brazil, results in complete control of parasite growth (Childs et al. 1984, Lima et al. 1999). Contrary to what has been observed with $L$. major, infection by $L$. braziliensis does not induce a strong IL-4 production early in the course of the disease (DeKrey et al. 1998). In view of this observation, we decided to investigate how this inability to induce a strong Th2 response would affect the course of infection in the absence of a Th1 inducer, i.e. IL-12. The present study shows that infection of IL-12p40-/- mice with L. braziliensis results in development of chronic lesions that fail to heal but, nevertheless, do not develop progressively as demonstrated for mice infected with L. major (Mattner et al. 1996, 1997b), suggesting that in the absence of high levels of IL-4, mechanisms other than induction of Th1 cells by IL-12 may be relevant for parasite control.

In view of the fact that IFN- $\gamma$ production is paramount to the control of this parasite (Fig. 1, DeKrey et al. 1998), we can assume that the partial control of the lesions in IL12 p40 -/- mice is dependent on the presence of some level of IFN- $\gamma$ production. We were able to detect low levels of IFN- $\gamma$ production by lymph node cells from infected IL12 p40 -/- animals. Although we did not determine the source of this IFN- $\gamma$ production, the experimental conditions used to stimulate the cells suggest that it may be associated to CD4+ T cells (Belkaid et al. 2002). It has been recently demonstrated that, although delayed, generation of Th1 cells in the absence of IL-12 is possible (Jankovic et al. 2002). It was suggested that IL-18 would be driving this differentiation (Okamura et al. 1995). The delayed generation of a small population of Th1 cells in IL-12p40 -/- mice infected with L. braziliensis would allow for the partial control of the lesion at a chronic stage of the disease. Alternatively, $\mathrm{CD}^{+} \mathrm{T}$ cells could be the effector cells controlling parasite growth in our model. Production of IFN- $\gamma$ by these cells has been reported to be independent of the action of IL-12 (Wan et al. 2001). The participation of $\mathrm{CD}^{+} \mathrm{T}$ cells in the control of Leishmania infection is well established, both in mice and humans (Coutinho et al. 1996, 1998, Huber et al. 1998, Holaday 2000, Belkaid et al. 2002). The involvement of CD4 ${ }^{+}$and/ or $\mathrm{CD}^{+}$cells in the control of the infection by $L$. braziliensis in IL-12p40 -/- mice is currently being investigated.

Lastly, our results show an interesting finding concerning TNF production by lymph node cells from infected mice (Fig. 3, bottom panel). Elevated levels of TNF were detected in cultures (both C57BL/6 and IL-12p40 -/-) as compared to those reported for mice infected with L. major under the same culture conditions (Vieira et al. 1996, Wei et al. 1999). Interestingly, patients with mucocutaneous leishmaniasis, a disease usually caused by $L$. braziliensis, show elevated levels of TNF in the serum 
(da Cruz et al. 1996). It would be interesting to verify the role of this cytokine in the control of infection in this model.

\section{ACKNOWLEDGMENTS}

To Maria Helena Alves de Oliveira, Antônio Vaz Mesquita, and Antônio Celso Torres for dedicated animal care.

\section{REFERENCES}

Afonso LCC, Scott P 1993. Immune responses associated with susceptibility of C57BL/10 mice to Leishmania amazonensis. Infect Immun 61: 2952-2959.

Barral A, Barral-Netto M, Yong, EC, Brownell CE, Twardzik DR, Reed SG 1993. Transforming growth factor $\beta$ as a virulence mechanism for Leishmania braziliensis. Proc Natl Acad Sci USA 90: 3442-3446.

Barral-Netto M, Barral A, Brownell CE, Skeiky YAW, Ellingsworth LR, Twardzik DR, Reed SG 1992. Transforming growth factor- $\beta$ in leishmanial infection: a parasite escape machanism. Science 257: 545-548.

Belkaid Y, von Stebut E, Mendez S, Lira R, Caler E, Bertholet S, Udey MC, Sacks D 2002. CD8 ${ }^{+}$T cells are required for primary immunity in C57BL/6 mice following low-dose, intradermal challenge with Leishmania major. J Immunol 168: 3992-4000.

Belosevic M, Finbloom DS, van der Meide PH, Slayter MV, Nacy CA 1989. Administration of monoclonal anti IFN- $\gamma$ antibodies in vivo abrogates natural resistance of $\mathrm{C} 3 \mathrm{H} / \mathrm{HeN}$ mice to infection with Leishmania major. J Immunol 143: 266-274.

Brombacher F, Dorfmuller A, Magram J, Dai WJ, Kohler G, Wunderlin A, Palmer-Lehmann K, Gately MK, Alber G 1999. IL-12 is dispensable for innate and adaptive immunity against low doses of Listeria monocytogenes. Int Immunol 11: 325-332.

Chan SH, Kobayashi M, Santoli D, Perussia B, Trinchieri G 1992. Mechanisms of IFN- $\gamma$ induction by natural killer cell stimulatory factor (NKSF/IL-12). Role of transcription and mRNA stability in the synergistic interaction between NKSF and IL-2. J Immunol 148: 92-98.

Chan SH, Perussia B, Gupta JW, Kobayashi M, Pospisil M, Young HA, Wolf SF, Young D, Clark SC, Trinchieri G 1991. Induction of interferon gamma production by natural killer cell stimulatory factor: characterization of the responder cells and synergy with other inducers. J Exp Med 173: 869879.

Childs GE, Lightner LK, McKinney L, Groves MG, Price EE, Hendricks LD 1984. Inbred mice as model hosts for cutaneous leishmaniasis. I. Resistance and susceptibility to infection with Leishmania braziliensis, L. mexicana, and $L$. aethiopica. Ann Trop Med Parasitol 78: 25-34.

Coutinho SG, da Cruz AM, Bertho AL, Santiago MA, De-Luca P 1998. Immunologic patterns associated with cure in human American cutaneous leishmaniasis. Braz J Med Biol Res 31: 139-142.

Coutinho SG, Oliveira MP, da Cruz AM, de Luca PM, Mendonça SC, Bertho AL, Soong L, McMahon-Pratt D 1996. T-cell responsiveness of American cutaneous leishmaniasis patients to purified Leishmania pifanoi amastigote antigens and Leishmania braziliensis promastigote antigens: immunologic patterns associated with cure. Exp Parasitol 84: 144-155.

da Cruz AM, de Oliveira MP, de Luca PM, Mendonça SC, Coutinho SG 1996. Tumor necrosis factor- $\alpha$ in human American tegumentary leishmaniasis. Mem Inst Oswaldo Cruz 91: 225-229.
DeKrey GK, Lima HC, Titus RG 1998. Analysis of the immune responses of mice to infection with Leishmania braziliensis. Infect Immun 66: 827-829.

Del Rio L, Buendia AJ, Sanchez J, Gallego MC, Caro MR, Ortega N, Seva J, Pallares FJ, Cuello F, Salinas J 2001. Endogenous interleukin-12 is not required for resolution of Chlamydophila abortus (Chlamydia psittaci serotype 1) infection in mice. Infect Immun 69: 4808-4815.

Heinzel FP, Sadick MD, Holaday BJ, Coffman RL, Locksley RM 1989. Reciprocal expression of interferon gamma or IL4 during the resolution or progression of murine leishmaniasis. Evidence for expansion of distinct helper T cell subsets. J Exp Med 169: 59-72.

Heinzel FP, Sadick MD, Mutha SS, Locksley RM 1991. Production of interferon gamma, interleukin 2, interleukin 4, and interleukin 10 by CD4+ lymphocytes in vivo during healing and progressive murine leishmaniasis. Proc Natl Acad Sci USA 88: 7011-7015.

Heinzel FP, Schoenhaut DS, Rerko RM, Rosser LE, Gately MK 1993. Recombinant Interleukin 12 cures mice infected with Leishmania major. J Exp Med 177: 1505-1509.

Holaday BJ 2000. Role of CD8+ T cells in endogenous interleukin-10 secretion associated with visceral leishmaniasis. Mem Inst Oswaldo Cruz 95: 217-220.

Hsieh CS, Macatonia SE, Tripp CS, Wolf SF, O'Garra A, Murphy KM 1993. Development of Th1 CD4+ T cells through IL-12 produced by Listeria-induced macrophages. Science 260: 547-549.

Huber M, Timms E, Mak TW, Llinghoff M, Lohoff M 1998. Effective and long-lasting immunity against the parasite Leishmania major in CD8-deficient mice. Infect Immun 66: 3968-3970.

Jankovic D, Kullberg MC, Hieny S, Caspar P, Collazo CM, Sher A 2002. In the absence of IL-12, CD $4^{+} \mathrm{T}$ cell responses to intracellular pathogens fail to default to a Th2 pattern and are host protective in an IL-10 $0^{-/-}$setting. Immunity 16: 429-439.

Jones DE, Ackermann MR, Wille U, Hunter CA, Scott P 2002. Early enhanced Th1 response after Leishmania amazonensis infection of C57BL/6 Interleukin-10-deficient mice does not lead to resolution of infection. Infect Immun 70: 2151-2158.

Lattime SC, Stopacciaro A, Stutman O 1988. Limiting dilution analysis of TNF producing cells in $\mathrm{C} 3 \mathrm{H} / \mathrm{HeJ}$ mice. $J$ Immunol 141: 3422-3428.

Liew FY 1989. Functional heterogeneity of CD4+ T-cells in leishmaniasis. Immunol Today 10: 40-45.

Lima,HC, DeKrey GK, Titus RG 1999. Resolution of an infection with Leishmania braziliensis confers complete protection to a subsequent challenge with Leishmania major in BALB/c mice. Mem Inst Oswaldo Cruz 94: 71-76.

Lowry OH, Rosebrough NJ, Farr AL, Randall RJ 1951. Protein measurement with the folin phenol reagent. J Biol Chem 193: 265-275.

Macatonia SE, Hsieh CS, Murphy KM, O’Garra A 1993. Dendritic cells and macrophages are required for Th1 development of CD4+ T cells from alpha beta TCR transgenic mice: IL-12 substitution for macrophages to stimulate IFNgamma production is IFN-gamma- dependent. Int Immunol 5: 1119-1128.

Magram J, Connaughton SE, Warrier RR, Carvajal DM, Wu CY, Ferrante J, Stewart C, Sarmiento U, Faherty DA, Gately MK 1996. IL-12-Deficient mice are defective in IFN $\gamma$ production and type 1 cytokine responses. Immunity 4: 471481.

Mattner F, Alber G, Magram J, Kopf M 1997a. The role of IL12 and IL-4 in Leishmania major infection. Chem Immunol 68: 86-109. 
Mattner F, Di Padova K, Alber G 1997b. Interleukin-12 is indispensable for protective immunity against Leishmania major. Infect Immun 65: 4378-4383.

Mattner F, Magram J, Ferrante J, Launois P, Di Padova K, Behin R, Gately MK, Louis JA, Alber G 1996. Genetically resistant mice lacking interleukin-12 are susceptible to infection with Leishmania major and mount a polarized Th2 cell response. Eur J Immunol 26: 1553-1559.

National Research Council 1996. Guide for the Care and Use of Laboratory Animals, National Academy Press, Washington, DC, $140 \mathrm{pp}$.

Okamura H, Tsutsi H, Komatsu T, Yutsudo M, Hakura A, Tanimoto T, Torigoe K, Okura T, Nukada Y, Hattori K 1995. Cloning of a new cytokine that induces IFN- $\gamma$ production by T cells. Nature 378: 88-91.

Park AY, Hondowicz BD, Scott P 2000. IL-12 is required to maintain a Th1 response during Leishmania major infection. J Immunol 165: 896-902.

Samuelson J, Lerner E, Tesh R, Titus RG 1991. A mouse model of Leishmania braziliensis braziliensis infection produced by coinjection with sand fly saliva. J Exp Med 173: 41-54.

Scharton-Kersten T, Scott P 1995. The role of the innate immune response in Th1 cell development following Leishmania major infection. J Leukoc Biol 57: 515-522.

Scharton-Kersten T, Caspar P, Sher A, Denkers EY 1996. Toxoplasma gondii: evidence for interleukin-12-dependent andindependent pathways of interferon-gamma production induced by an attenuated parasite strain. Exp Parasitol 84: 102-114.

Scott P 1989. The role of TH1 and TH2 cells in experimental cutaneous leishmaniasis. Exp Parasitol 68: 369-372.

Scott P 1991. IFN- $\gamma$ modulates the early development of Th1 and Th2 responses in a murine model of cutaneous leishmaniasis. J Immunol 147: 3149-3155.

Scott P, Pearce E, Cheever AW, Coffman RL, Sher A 1989. Role of cytokines and CD4+ T cell subsets in the regulation of parasite immunity and disease. Immunol Rev 112: 161-182.

Seder RA, Gazzinelli RT, Sher A, Paul WE 1993. Interleukin 12 acts directly on $\mathrm{CD}^{+} \mathrm{T}$ cells to enhance priming for interferon- $\gamma$ production and diminishes interleukin 4 inhibition of such priming. Proc Natl Acad Sci USA 90: 10188-10192.

Soong L, Chang CH, Sun J, Longley Jr BJ, Ruddle NH, Flavell
RA, McMahon-Pratt D 1997. Role of CD4+ T cells in pathogenesis associated with Leishmania amazonensis infection. J Immunol 158: 5374-5383.

Stobie L, Gurunathan S, Prussin C, Sacks DL, Glaichenhaus N, Wu CY, Seder RA 2000. The role of antigen and IL-12 in sustaining Th1 memory cells in vivo: IL-12 is required to maintain memory/effector Th1 cells sufficient to mediate protection to an infectious parasite challenge. Proc Natl Acad Sci USA 97: 8427-8432.

Sypek JP, Chung CL, Mayor SEH, Subramanyam JM, Goldman SJ, Sieburth DS, Wolf SF, Schaub RG 1993. Resolution of cutaneous leishmaniasis: interleukin 12 initiates a protective Th1 immune response. J Exp Med 177: 1797-1802.

Trinchieri G 1993. Interleukin-12 and its role in the generation of Th1 cells. Immunol Today 14: 335-338.

Tripp CS, Wolf SF, Unanue ER 1993. Interleukin 12 and tumor necrosis factor- $\alpha$ are costimulators of interferon- $\gamma$ production by natural killer cells in severe combined immunodeficiency mice with listeriosis, and interleukin 10 is an physiologic antagonist. Proc Natl Acad Sci USA 90: 37253729.

Vieira LQ, Goldschmidt M, Nashleanas M, Pfeffer KTM, Scott P 1996. Mice lacking the TNF receptor p55 fail to resolve lesions caused by infection with Leishmania major, but control parasite replication. J Immunol 157: 827-835.

Vieira LQ, Hondowicz BD, Afonso LCC, Wysocka M, Trinchieri G, Scott P 1994. Infection with Leishmania major induces interleukin-12 production in vivo. Immunol Lett 40: 157161.

Wan Y, Lu L, Bramson JL, Baral S, Zhu Q, Pilon A, Dayball K 2001. Dendritic cell-derived IL-12 is not required for the generation of cytotoxic, IFN- $\gamma$-secreting, $\mathrm{CD} 8^{+} \mathrm{CTL}$ in vivo. J Immunol 167: 5027-5033.

Wang ZE, Reiner SL, Zheng S, Dalton DK, Locksley RM 1994. CD4+ effector cells default to the Th2 pathway in interferon- $\gamma$ deficient mice infected with Leishmania major. $J$ Exp Med 179: 1367-1371.

Wei XQ, Leung BP, Niedbala W, Piedrafita D, Feng GJ, Sweet M, Dobbie L, Smith AJ, Liew FY 1999. Altered immune responses and susceptibility to Leishmania major and Staphylococcus aureus infection in IL-18-deficient mice. $J$ Immunol 163: 2821-2828. 